\title{
Metallic contamination of vegetables: causes and approach of solutions through environmental education
}

\begin{abstract}
This study aims to evaluate the causes of metallic contamination of vegetables produced in Grand-Popo in Benin and to propose some approaches to solutions through environmental education. Specifically, the assessment involved metal contamination by poultry manure used extensively by growers for crop fertilization. Laboratory analyzes were conducted to identify four heavy metals (copper, lead, cadmium and iron) in vegetable and poultry manure samples. The average levels of lead in carrots, big nightshade and tomato are respectively 41, 6 and 38 times higher than Benin standards while those of cadmium are respectively 25 , 6 and 40 times. These levels revealed a relation between human activities and the degrees of contamination. The effects of piles of filth are not excluded in this contamination, the consequences of which are the health risks for consumers and producers. To remedy this situation, it is necessary to take steps to identify all potential sources of contamination. Those sources must be especially, domestic and commercial activities, in order to abandon or control them. In addition, some environmental education leads are proposed to help mitigate the impact of non-agricultural activities in this metal contamination.
\end{abstract}

Volume 3 Issue 2 - 2018

\author{
Atidegla Capo Seraphin \\ Faculty of Agronomic Sciences, University of Abomey-Calavi, \\ Benin \\ Correspondence: Atidegla Capo Seraphin, Faculty of \\ Agronomic Sciences, University of Abomey-Calavi, \\ BP: 433 Abomey-Calavi, Benin, Tel 229958180 58/229 9777 \\ 46 28, Email atideglaser@gmail.com
}

Received: April 17, 2018 | Published: June 042018

Keywords: market gardening, heavy metals, vegetables, health risks, benin

Abbreviations: ABE, agency benin environmental; ETM, trace metal elements; SNK, student new mankeuls; RNIE 1, national inter state route 1; DFI, federal department of the interior; MTE, federal metallic trace elements; IEC, information, education and communication

\section{Introduction}

If according to Atidégla ${ }^{1}$ market gardening in Grand-Popo enjoys easy access to water from groundwater used for watering crops, it must also deal with constraints including land pressure and infertility coastal soils ${ }^{2}$ and the low or unskilled workforce handling delicate products: fertilizers and pesticides. ${ }^{3}$ Despite this difficulty, producers in Grand-Popo have adopted intensification as a strategy to improve the productivity of agricultural land; ${ }^{4}$ what Fall et al., ${ }^{5}$ according to which the supply of fertilizers to soils is a necessity for nutritious vegetable crops. However, intensification through the misuse of mineral and organic fertilizers for soil fertilization is not without impact on the quality and conservation of coastal ecosystems and their resources. A study conducted by Agbossou \& Sanny ${ }^{6}$ on behalf of the Benin Environmental Agency (ABE) revealed the presence of several trace metal elements (ETM) in market garden crops produced on the perimeters urban and peri-urban Cotonou, Porto-Novo and Parakou. Indeed, during their transport and dispersion in water, air and soil, contaminants from fertilizers, pesticides and nature are absorbed by vegetation and are then found in the food chain.

This is why people consuming vegetable products are not immune to contamination. The market places of Grand-Popo, particularly those of the districts of Grand-Popo and Agoué, are not spared. Therefore, one of the risks to be feared and which is linked to human actions is the accumulation of heavy metals in water, soil and vegetables. Considering the mineral and organic pollution load produced, the quality of the various resources (groundwater, soils and vegetable products) is therefore threatened by the different forms of pollutants. The heavy metals associated with different discharges (wild dumps, heaps of refuse, exhaust gases, etc.) represent the most feared pollutants for these environments. The reason is that of their concentration by certain living organisms and their involvement in bioaccumulation phenomena and bio amplification in food chains. To check potential contamination of vegetables by heavy metals from various sources including poultry manure used, we set up an experiment in farmland from 2009 to 2010 during our doctoral studies. The purpose of this work is to evaluate the residual toxicity metals such as lead $(\mathrm{Pb})$, cadmium $(\mathrm{Cd})$, copper $(\mathrm{Cu})$ and iron $(\mathrm{Fe})$ in vegetables in the perimeters of urban and peri-urban areas of GrandPopo and to offer education related to the environment to target populations.

\section{Material and methods}

\section{Study zone}

Located in the Department of Mono, bordering the Atlantic coast, the municipality of Grand-Popo is between $6^{\circ} 15^{\prime}$ and $6^{\circ} 25^{\prime}$ of latitude North and between $1^{\circ} 40^{\prime}$ and $1^{\circ} 55^{\prime}$ of longitude East with a surface of $240 \mathrm{~km}^{2}$. Its average altitude is $5 \mathrm{~m}$ above the sea. It extends over a length of $35 \mathrm{~km}$ of coastline and has a population of 40,335 inhabitants. ${ }^{8}$ Like the entire coastal region, it enjoys a subequatorial climate, characterized by small temperature variations (annual average of $27.4^{\circ} \mathrm{C}$ ) and bimodal rainfall:

a) A long dry season from November to April

b) A large rainy season from April to July;

c) A short dry season from August to September

d) A short rainy season from September to October. The average annual rainfall is $882.1 \mathrm{~mm}$.

The study area is characterized by marine sandy soils, little 
evolved, leached, very filtering and porous on the first 2 horizons (0$18 \mathrm{~cm}$ and $18-40 \mathrm{~cm})$, with a slightly basic $\mathrm{pH}(7.3$ and 7,5$)$. These are continuously cultivated soils with no fallow for at least ten years. Finally, it is part of the geomorphological complex of the littoral zone which is a very complex domain because of the diversity and the dynamism of the elements which it associates: the sea, the deltas, the lagoons, the lakes, the marshes and the coastlines.

\section{Agronomic tests}

The experimental device was installed in real-life at the YodoCondji and Ayi-Guinnou sites. The effects of poultry manure and mineral fertilizers on vegetables are tested at the Yodo-Condji and AyiGuinnou sites using a two-factor split plot (treatment and vegetable) and three replicates. The tests were conducted over four successive production seasons from 2009 to 2010. The variables measured concern copper, lead, iron and cadmium contents. The secondary vegetable factor consisted of three types: tomato, large nightshade and carrot, and the main factor "treatment" were the four T0, T1, T2 and T3 modalities:

i) T0 (control): no manure.

ii) T1: 1.2t/ha of NPK in 3 inputs and 1.2t/ha of urea in 3 inputs, that is to say $0.4 \mathrm{t} / \mathrm{ha}$ of each chemical fertilizer by application.

iii)T2: $20 \mathrm{t} / \mathrm{ha}$ of poultry manure as a single intake; $1.2 \mathrm{t} / \mathrm{ha}$ of NPK in 3 inputs and 1.2t/ha of urea in 3 inputs, that is to say $0.4 \mathrm{t} / \mathrm{ha}$ of each chemical fertilizer per application.

iv) T3: 40t/ha of poultry droppings in 2 divided inputs of 25 and 15t/ ha. The poultry droppings used consist of poultry droppings and wood shavings, similar to droppings applied as organic fertilizer in the study area. The one applied during the test comes from the same breeding of broilers and layers and was bought in the breeding one month, after leaving the henhouse.

\section{Sampling and analysis of poultry droppings and vegetables}

Sampling of vegetables was done at the harvest of each campaign, 4 times during the trial. For poultry droppings, the sample was taken before each campaign, at the farm at the time of purchase, following the procedure described above to obtain a sample of one $\mathrm{kg}$. All samples are sealed, identified, kept refrigerated and transported to the laboratory the same day. The variables measured concern the contents of four heavy metals iron, $\mathrm{Fe}, \mathrm{Pb}, \mathrm{Cu}$, and $\mathrm{Cd}$. The analyzes are carried out in Cotonou in the Laboratory of Quality Control of Water and Food of the Department of Hygiene and Basic Sanitation of the Ministry of Health. Overall, 96 composite samples of all three vegetables from plots that received four separate types of manures were analyzed. The same was made for the 4 samples of poultry dung. The methods used for the analyzes are summarized in the $\mathrm{HACH}$ mineralization and in the DR 2800 Spectrophotometer using the Dithizone methods for lead and cadmium, 1,10- phenanthroline for iron and Bicinchoninate for copper.

\section{Statistical treatment of data}

Repetitive variance analyzes were performed by the SAS software version 9.2, to test the effects of the various factors (treatment and vegetables) over time with regard to the heavy metal content. To stabilize the variances, each of the four variables considered $(\mathrm{Fe}, \mathrm{Cu}$,
$\mathrm{Pb}$ and $\mathrm{Cd}$ ) was log-transformed according to the following relation, $y=\ln (x+1)$ where " $x$ " is the number observed for each of the variables considered and " $y$ " is the result of the transformation. The adjusted means of the three variables were compiled with the corresponding coefficients of variation. Student-Newman-Keuls (SNK) tests distinguished means by high-lighting the different groups of homogenous treatments.

\section{Results}

\section{Residual toxicity of heavy metals from poultry droppings used}

Concentrations of heavy metals varied greatly from one campaign to another. In addition to iron, the average levels of which exceeded European standards in the first to third seasons, those of other heavy metals (copper, lead and cadmium) in poultry droppings were far below these standards (Table 1). Their evolution was as follows:

i) Iron was the most remarkable with a concentration for campaign 1 of $1400.06 \mathrm{mg} / \mathrm{kg}$ exceeding twice the European norms allowed for composts but experiencing a vertiginous decline from one season to another to fall suddenly from $982 \mathrm{mg} / \mathrm{kg}$ in season 3 to $18 \mathrm{mg} / \mathrm{kg}$ in season 4 .

ii) Copper showed the same trend from $63.76 \mathrm{mg} / \mathrm{kg}$ in campaign 1 at $37.36 \mathrm{mg} / \mathrm{kg}$ in season 4 but in a less drastic manner.

iii)Lead and cadmium showed either traces or very low values below the limit values. These results show that, often, the poultry droppings lead to pollution by iron.

\section{Effects of time (4 campaigns), vegetables, treatments and sites on heavy metals contents (Fe, $\mathrm{Cu}, \mathrm{Pb}$ and $\mathrm{Cd}$ )}

The results of the repeated measures variances analyze are presented in Table 2. It appears that with respect to time (from one campaign to another), the levels recorded by all the parameters were significant at 0.001 .This gives evidence of the importance of time effect (succession of campaigns) on the desired parameters. The same degree of significance was observed with the "Time* Vegetable" interaction for copper and iron while for lead and cadmium, the time was significant at 0.05 . It is the same for the interactions "Time* Sites" and "Time* Vegetable* Treatment" respectively for copper and cadmium.

\section{Influence of treatments on vegetable contamination by heavy metals}

Average heavy metal content per site when vegetables are considered all together

Figure 1 illustrates the average levels of heavy metals per campaign at both sites when all vegetables and treatments are combined. It shows that there is not a large variation of the means between sites, but in spite of this, the vegetables of the site of Ayi-Guinnou have little more heavy metals than those of Yodo- Condji. In addition, Figure 2 shows the average levels per treatment when campaigns and sites are combined. This allowed deducing that the T0 treatment was the most efficient. The average iron levels were the most important and evolved according to the order $\mathrm{T} 2<\mathrm{T} 1<\mathrm{T} 3<\mathrm{T} 0$ whereas $\mathrm{Cu}$ and $\mathrm{Pb}$ were more present under $\mathrm{T} 0$. 
Table I Average contents of heavy metals used in poultry droppings

\begin{tabular}{llllll}
\hline Parameters(mg/kg) & Campagne I & Campagne 2 & Campagne 3 & Campagne 4 $\begin{array}{l}\text { European standards for } \\
\text { composts (mg/kg) }\end{array}$ \\
\hline Total & 1400,06 & 1274,56 & 982 & 18 & 600 \\
Copper & 63,76 & 59,18 & 56 & 37,36 & $100-1000$ \\
Lead & 0,0012 & 0,683 & 1,6 & 1,6 & $150-1000$ \\
Cadmium & 0,0019 & 1138 & 0,36 & 0,95 & 5 \\
\hline
\end{tabular}

Table 2 Results of ANOVA on repeated measurements:Values of $F$ and levels of significance

\begin{tabular}{|c|c|c|c|c|c|}
\hline \multirow[t]{2}{*}{ Sources } & \multicolumn{3}{|c|}{ Fisher values } & \multirow[b]{2}{*}{ Lead } & \multirow[b]{2}{*}{ Cadmium } \\
\hline & DDL & Ferrous & Copper & & \\
\hline Time & 3 & $104,9 \mid * * *$ & $55,88^{* * *}$ & $31,11 * * *$ & $45,4 I * * *$ \\
\hline Time*Sites & 3 & $0,80 \mathrm{~ns}$ & $4,67^{*}$ & I,63ns & I,73ns \\
\hline Time*Vegetable & 6 & $6,24 * * *$ & $7,52 * * *$ & $3,22^{*}$ & $3,06 *$ \\
\hline Treatment*Time & 9 & $0,5 \mathrm{Ins}$ & I,33ns & $0,49 \mathrm{~ns}$ & $\mathrm{I}, 8 \mathrm{Ins}$ \\
\hline Time* Sites* Vegetable & 6 & I,88ns & I,40ns & I,67ns & $0,12 \mathrm{~ns}$ \\
\hline Time* Sites* Processing & 9 & $0,80 \mathrm{~ns}$ & $2,08 \mathrm{~ns}$ & $0,58 \mathrm{~ns}$ & $0,63 \mathrm{~ns}$ \\
\hline Time*Vegetable* Treatment & 18 & $0,93 \mathrm{~ns}$ & $0,72 \mathrm{~ns}$ & $0,49 n s$ & $2,14 *$ \\
\hline
\end{tabular}

*, significatif à 0,$05 ; * *$, significatif à 0,01 ; ***, significatif à 0,001 ; ns, non significatif à 0,05

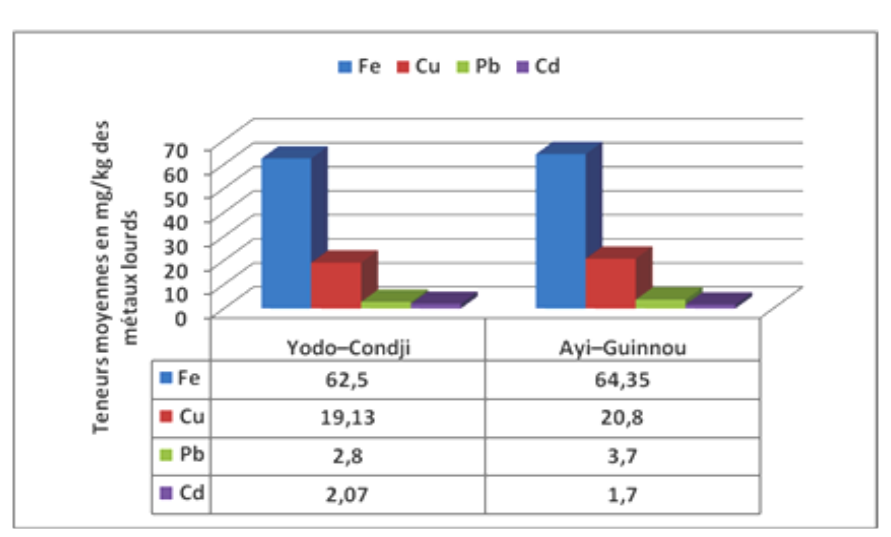

Figure I Average heavy metal content per site under the four campaigns.

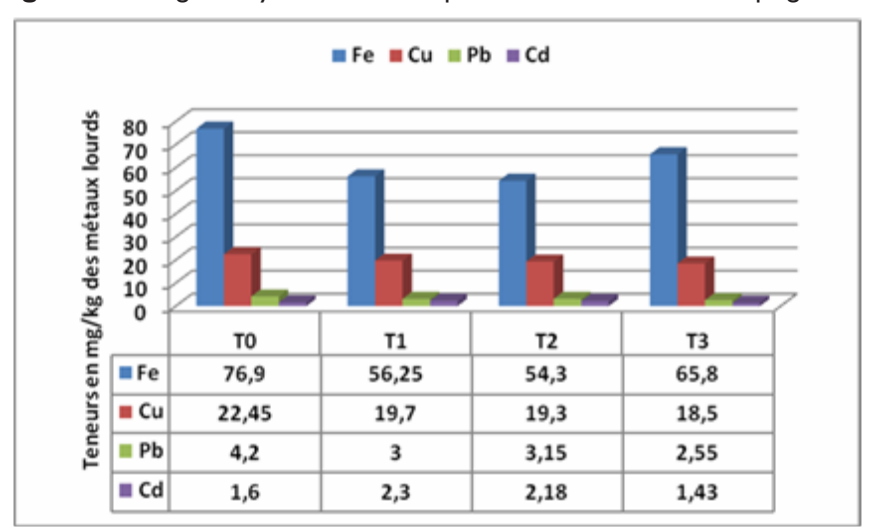

Figure 2 Average contents of heavy metals by treatment under the four campaigns.

\section{Average heavy metals content per vegetable for the four seasons}

At the end of the four seasons, it appeared that the average levels of heavy metals varied greatly from one heavy metal to another and according to the vegetable (Figure 3). Roughly speaking, it emerges that:

a. The iron was very concentrated in all the vegetables produced with leading the big nightshade, then the carrot and finally the tomato. The Beninese and European standards of the Federal Department of the Interior (DFI) are silent with regard to iron. Copper was present at not very high but abnormal and not significantly different rates among the 3 vegetables. The tomato has concentrated the highest value against the lowest for the tomato. The levels recorded for all vegetables exceed the DFI standards $(15 \mathrm{mg} / \mathrm{kg})$;

b. The lead levels exceed for all vegetables Benin standards $(0.30 \mathrm{mg} /$ $\mathrm{kg}$ for large nightshade, $0.10 \mathrm{mg} / \mathrm{kg}$ for carrots and tomatoes) and those of the DFI $(0.1 \mathrm{mg} / \mathrm{kg})$ whatever vegetable).

c. Cadmium also gave levels higher than those recommended by Benin $(0.2 \mathrm{mg} / \mathrm{kg}$ for large nightshade, $0.05 \mathrm{mg} / \mathrm{kg}$ for tomatoes and $0.1 \mathrm{mg} / \mathrm{kg}$ for carrots $)$ and DFI $(0.1 \mathrm{mg} / \mathrm{kg}$ for all vegetables $)$. The order of preference of the heavy metals by the 3 vegetables was $\mathrm{Fe}, \mathrm{Cu}, \mathrm{Pb}$ and $\mathrm{Cd}$. In conclusion, the vegetables analyzed were polluted by lead and cadmium. Concerning the influence of non-agricultural activities on the contamination of vegetables by heavy metals (Figure 2), we can say that the T0 treatment reflects to a certain extent the influence of piles of garbage (Figure 4), garbage and exhaust. Overall, all vegetables had high T0 levels and the responsibilities of T1, T2 and T3 (fertilizer treatments and 
/ or poultry manure) were not clearly established in the different grades recorded.

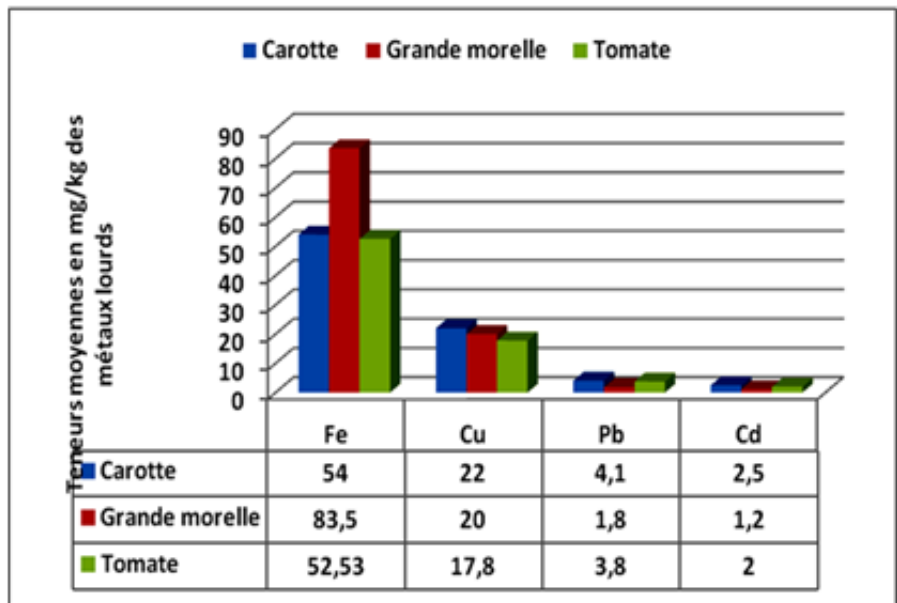

Figure 3 Average heavy metals content per vegetable under the four seasons.

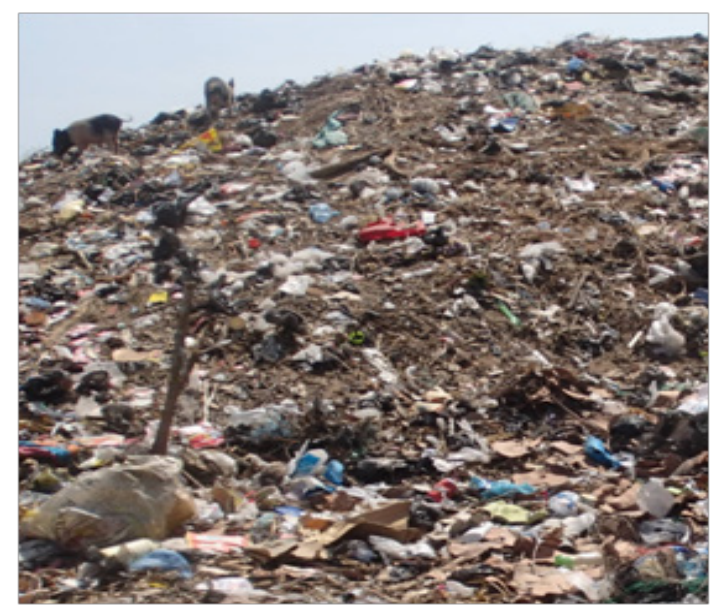

Board A

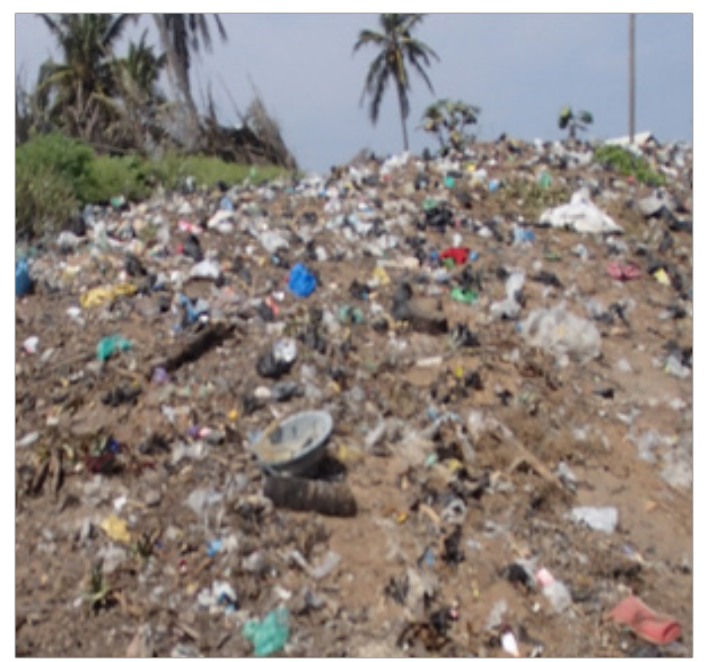

Board B

Figure 4 Heap of filth next to the vegetable sites.

\section{Discussion}

Vegetable contamination by heavy metals was not caused by applied fertilizers (mineral fertilizer and poultry manure)

\section{T0 treatment (Witness)}

The remarkable contamination of all vegetables under $\mathrm{T} 0$ by heavy metals may be justified by the natural presence of said heavy metals in soil, water and the atmosphere. In fact, some of the water that falls on the ground (rain, snow and irrigation) is evacuated by evaporation or surface runoff, while the second enters the soil and goes to the roots of the plants, by gravity, to the roots, deep horizons and groundwater. During these transports, the water is charged in dissolved trace elements. The importance of these transfers varies greatly depending on the nature of the soil and metals. ${ }^{9}$ However, the fate of heavy metals in the soil depends on the metal and the soil in the presence: one part is volatilized (mercury), another part goes with the runoff and the last one enters the soil. If the metal is soluble, it will pass into the sheets and / or plants; if it is insoluble, it will stay in the ground. As for the heavy metals suspended in the atmosphere and which could not fall to the ground with the rains, the wind carries them and, under the action of the latter, they are deposited either on the leaves of the plants or on the ground. In terms of these heavy metals, we have mainly lead, the highest content of which has been recorded in all vegetables. The case of their origin from piles of filth is therefore not excluded.

\section{$\mathrm{TI}, \mathrm{T} 2$ and $\mathrm{T} 3$ treatments}

The chemical contamination of vegetables by heavy metals under the treatments T1, T2 and T3 did not bring anything particular compared to the contents obtained under T0. This confirms the statistical results on repeated measures according to which the treatments were not significant. For example, the rates recorded by large morelle for $\mathrm{Cu}$ under T1 $(28.5 \mathrm{mg} / \mathrm{kg})$ and T3 $(32.2 \mathrm{mg} / \mathrm{kg})$ were lower than that obtained under T0 $(33.3 \mathrm{mg} / \mathrm{kg})$ and it was the same for the $\mathrm{Pb}$. This pattern has varied from one vegetable to another, but what was common was the lack of direct influence of the treatments applied to vegetables outside the dung that has a little influenced the iron content for the carrot. For this reason, we can affirm that apart from lead, whose origin is much more water and the fallout of atmospheric particles, vegetables have been contaminated by the stock of heavy metals that existed in floor. This suggests that the critical load of the soil is reached and that it no longer continues to play its role effectively buffer so that the metal trace elements sought easily reach the water table. The non-detection of certain heavy metals or the traces revealed by others may be justified by the fact that the soil nevertheless continues to play its depuration role thus preventing the metallic trace elements from reaching the water table. However, in the Cotonou market gardening sites where similar work was carried out by Agbossou \& Sanny ${ }^{6}$, overrun of the standards allowed by the heavy metals content (lead, iron, copper, cadmium, etc.) for most vegetables cultivated were justified by the use of compost based on household waste.

\section{Origins of lead and cadmium identified as pollutants of vegetables tested}

In addition to the natural origins known to heavy metals, the high levels recorded are also the result of several combined actions of man. These include: 
i. Poor agricultural practices involving the intensive and abusive use of organic fertilizers and pesticides (insecticides, fungicides and herbicides), situation confirmed by Kestemont ${ }^{10}$.

ii. Piles of garbage and household waste strewn across the study area and containing, among other things, significant proportions of used batteries, made from lead or cadmium-nickel, and pieces of lead used as weights in fishing nets.

It should be noted, for example, that in cadmium-nickel batteries, cadmium represents more than 15 to $20 \%$ of the weight of the cell. ${ }^{11}$ According to Arod $^{12}$, oysters (bivalve molluscs) in littoral zones are an important source of cadmium because they alone concentrate more than 100,000 times, or even more, cadmium. We can cite the smoke of cigarettes and paintings that are the common sources of these two metals that are also influenced by sea spray. More specifically, the high levels recorded for lead and cadmium could essentially come from:

a) Adulterated marine fuel traffic carried out in the years 19902000 on the coast of Grand-Popo whose base was Agoue for the conveyance of petroleum products to Togo. Through this trade, a large dose of carbonated lead migrates into the atmosphere and will settle on the leaves of vegetables and soil. Indeed, according to Semde ${ }^{13}$, if some of the heavy metals go directly into the soil and water, most of it is emitted into the atmosphere before joining the other two elements.

b) The development, in recent years, of the selling points of the adulterated gasoline along the arteries of the National Inter-State Route 1 (RNIE 1) from the entrance of the district of Grand-Popo to Hilla-Condji, at the Benin-Togo border crossing Agoué and

c) Exhaust gases from vehicles traveling on the RNIE 1 linking Cotonou and Lomé. In fact, most of the vegetable farms are located near this busy road, within a radius of 5 to $400 \mathrm{~m}$. In the same vein, similar work carried out in the market gardening sites located along the heavily trafficked roads in Kinshasa by Musibono $^{14}$ reported that the vegetables grown on these sites are polluted by the lead contained in the smoke released by the vehicles. Itself from the consumption of gasoline containing tetraethyl lead. He further noted that the lead content in both soil and vegetables decreases with increasing distance from the According to Carsignol ${ }^{15}$, risk situations arise when the path is close to specialized crops (market gardening, orchards, vineyards, tobaccos), organic, industrial contracted or labelled. In addition, motor traffic and road infrastructure are also sources of Metallic Trace Elements (MTE), but MTE pollution is only a fraction of chronic pollution from vehicles in circulation and wear and tear road equipment. ${ }^{15}$ However, it should be remembered that plants in general accumulate very little lead from the soil and traces of lead found on plants generally emanate from an atmospheric source. ${ }^{16}$

\section{Environmental education on contamination of vegetables by heavy metals}

Given the results of metallic contamination of vegetables and the potential sources identified, it is essential that joint action by the various actors in urban and peri-urban agriculture can be undertaken to mitigate the harm. Therefore, innovative cropping systems integrating fertilization practices that respect the environment and the health of populations will be designed. But before, it is important to inform, educate and communicate on the ins and outs of this situation through sessions of IEC (Information, Education and Communication). The sessions will focus, inter alia, on the following topics:

a) Why and how to produce in a healthy environment?

b) Why guarantee good quality for agricultural products?

c) What agricultural inputs should be used to ensure the nutritional quality of foods?

d) Where to install and why install urban and peri-urban operations away from roads and garbage piles;

e) Sensitization of the populations (producers, consumers and school environments) on the causes and consequences of the contamination of vegetables by the biocontaminants that are for example the heavy metals. ${ }^{17}$

\section{Conclusion}

The present work has highlighted the chemical contamination of vegetables by heavy metals such as: lead, cadmium, copper and iron. The evaluation of the results allowed recognizing from the agronomic tests, that the historical existence in the soils and the waters of the heavy metals sought influenced the levels observed for the vegetables tested. In addition, the study has highlighted the presence of heavy metals including some of the most formidable $(\mathrm{Pb}$ and $\mathrm{Cd})$ in vegetable products. Even those detected at relatively low concentrations are to be considered because of the phenomena of chronic toxicity and interaction effects. All these bio contaminants present certain risks for the health of populations and for the quality of natural resources. Therefore, to help mitigating this situation, the environmental education approach is proposed. It consists of sensitization sessions the main theme of which is to get people in general and producers in particular to understand the validity of the nutritional quality they must at all costs look for the products they deliver on the market. Indeed, preserving the health of the producer and the consumer is one of the major challenges of agricultural production. To achieve this, it is necessary to guarantee a good nutritional quality to agricultural products. To do this, before any development of the land, it is essential to adopt the following behaviours:

i. Keep the environment clean by making it free of all garbage, and especially not using it for defecation.

ii. Avoid using unapproved or prohibited fertilizers and pesticides.

iii. Apply the recommended doses and good practices during phytosanitary treatments or during the manure of soils and crops.

\section{Acknowledgments}

None.

\section{Conflict of interest}

Author declares no conflict of interest.

\section{References}

1. Atidégla CS. Effects of different doses of mineral fertilizers and poultry manure on the accumulation of biocontaminants and pollutants (fecal germs, nitrogen and phosphorus compounds, heavy metals) in water, soil and vegetables of Grand-Popo in Benin. PhD thesis, EDP / FLASH, University of Abomey-Calavi (UAC), Benin; 2011. 316 p. 
2. Midmore DJ, Jansen HGP. Supplying vegetables to Asian cities: is there a case for peri-urban production? Food Policy. 2003;28(1):13-27.

3. Kanda M, Wala K, Batawila K, et al. Le maraîchage périurbain à Lomé: pratiques culturales, risques sanitaires et dynamiques spatiales. Cahiers Agricultures. 2009;18(4):356-363.

4. Atidégla CS. Atouts et contraintes des modes d'irrigation dans les exploitations urbaines et périurbaines de la Commune de Grand-Popo. Mémoire de DEA, EDP/FLASH, Université d'Abomey-Calavi (UAC), Benin; 2006. 140 p.

5. Fall ST, Aminata N, Badiane AN. Integration horticulture-élevage: potentiel du système et contraintes. In: Fall ST, Fall AS, editors. In Cités Horticoles en Sursis? L'Agriculture Urbaine dans les Grandes Niayes au Sénégal. IDRC; 2000. 120 p.

6. Agbossou KE, Sanny S. Study of biocontaminants and migration of toxic agents. In vegetable crops in Benin. Beninese Agency for the Environment, Strand No. 1: Market perimeters of Houéyiho and Kouhounou in Cotonou, Benin; 2005. 85 p

7. Lenntech (2008) Treatment of water and air purification.

8. INSA. Fourth General Census of Population and Housing. Summary of results; 2009. $35 \mathrm{p}$

9. Vincent M. La pollution des eaux: Quel constat? Quels outils pour la caractériser? Revue Expert. 2000;48.
10. Kestemont L. Vegetables Les légumes à Charleroi sont riches en métaux lourds en m particulier le plomb. Revue Sciences et Santé. 2008;5:4.

11. Delire G. Des piles dans la nature? Le recyclage des piles. Cours d'épistémologie de la chimie. Agrégation en sciences. 2002;200(23):22.

12. Arod E. Se désintoxiquer des métaux lourds, une approche alimentaire globale. Article publié dans Biocontact. 2002; 14 p.

13. Semde I. Contribution du Burkina Faso à l'étude sur le plomb et le cadmium. Ministère de l'Environnement et du Cadre de vie, Direction Générale de 1'Amélioration du Cadre de Vie, 2005; 26 p.

14. Musibondo D. Pollution au plomb des légumes cultivés le long des artères publiques à Kinshasa. IRNB. Département Scientifique, Acte de colloque publié par courrier des lecteurs. 2003; 4 p.

15. SETRA. La pollution des Sols et des végétaux à proximité des routes: Les éléments traces métalliques (ETM). Note d'information. 2004;73:12.

16. ADEME. Connaissance et maîtrise des aspects sanitaires de l'épandage des boues. 1998; $22 \mathrm{p}$.

17. Assogba Komlan F, Anihouvi P, Achigan E, et al. Pratiques culturales et teneur en éléments anti nutritionnels (nitrates et pesticides) du Solanum macrocarpum au sud du Bénin. African Journal of Food Agriculture Nutrition and Development. 2007;7(4):7. 